\title{
THEORETICAL AND METHODOLOGICAL BASIS OF IMPLEMENTATION OF THE FOREIGN EXPERIENCE OF ADMINISTRATIVE REGULATION IN THE SYSTEM OF PUBLIC ADMINISTRATION
}

\section{ТЕОРЕТИКО-МЕТОДОЛОГІЧНІ ЗАСАДИ ІМПЛЕМЕНТАЦЇ̈ ЗАРУБІЖНОГО ДОСВІДУ АДМІНІСТРАТИВНОГО РЕГУЛЮВАННЯ В СИСТЕМІ ПУБЛІЧНОГО УПРАВЛІННЯ}

\section{Lozytska Iryna ${ }^{1}$ \\ Bashtannyk Vitalii ${ }^{2}$}

DOI: http://dx.doi.org/10.30525/978-9934-571-29-9_7

\begin{abstract}
The article examines various approaches to the principles of administrative reform of public administration based on the introduction of foreign experience. This study is based on the use of a set of general scientific and special scientific methods. The basis of the methodology of the article is a systematic approach, methods of analysis and synthesis, generalizations, comparative-historical method in accordance with the subject of research. The system approach allowed to study the basic components of the process of implementing the foreign experience of administrative reform through their internal integration. The application of the system approach allows us to analyse the organizational and legal foundations of the activity of the subjects of state administration, their functional characteristics and characteristics, and the tendencies of administrative regulation in the system of government bodies. The use of the comparative-historical method and the system approach was based on information systematized according to the criteria of analysis in accordance with the nature of the study.

The purpose of the study in the article is the development of organizational and institutional foundations and practical justification for the

\footnotetext{
${ }^{1}$ Postgraduate Student of the Department of Law and European Integration,

Dnipropetrovsk Regional Institute of Public Administration

of the National Academy of Public Administration under of the President of Ukraine;

Dnipropetrovsk District Administrative Court, judge, Ukraine

${ }^{2}$ Doctor of Science of Public Administration, Professor,

Professor of the Department of Law and European Integration,

Dnipropetrovsk Regional Institute of Public Administration

of the National Academy of Public Administration under of the President of Ukraine
} 
introduction of foreign experience of administrative reform in Ukraine. This goal is achieved through the implementation of research tasks: first, to analyse the peculiarities of the foreign experience of administrative reform and to determine on this basis the content and features of the administrative reform of the public administration in Ukraine; to reveal the importance of organizational and institutional support for the implementation of the administrative reform to improve the system of public authority, clarify the role of the legislative and legislative process to promote the implementation of administrative reform measures; to determine the actual problems of legal support for modern administrative reform in Ukraine.

Two key features of the introduction of foreign experience of administrative reform are underlined. First, the institutional definition of the legal framework (principles, methods and forms) of the functioning of the system of public administration. Secondly, the formation of the basis for the activities of government bodies in accordance with the concept of multi-level management.

The article presents conceptual approaches to the organizational principles of implementing foreign experience in the practice of public administration in Ukraine. A deepening of the research of reforming the system of public administration in the following areas is proposed: public administration as a system of public relations; ensuring human rights and freedoms as a vector of humanizing management; political and administrative aspects of the activities of government bodies; constitutional and legal bases of public administration in the context of supranational integration processes; analysis and adaptation of foreign experience in the transformation of public administration; development of regional and sectoral management in accordance with the requirements of EU law.

It is argued that the European integration processes contributed to the emergence of fundamentally new institutions of power and administrative mechanisms for coordinating positions and developing joint approaches to solve regional and global problems. Under such conditions, public administration in the process of reforming acquires new distinctive features, its subjectivity increases, and integrative management characteristics are strengthened. That is why the current state of the reform of the authorities is conditioned by the formation of an open administrative system, in which the principles, instruments, forms and methods of territorial government are constantly harmonized, the institution of delegation of authority is devel- 
oping, in accordance with the phenomenon of delegated management as an imperative of the general policy within the European Union.

It is established that in the process of studying foreign experience it is important: first, to analyse the peculiarities of the foreign experience of administrative reform and to determine on this basis the content and peculiarities of the administrative reform of the public administration system in Ukraine; secondly, to identify the importance of organizational support for the implementation of administrative reform to improve the system of state power, the role of the regulatory and legislative process in order to facilitate the implementation of administrative reform; thirdly, to determine the current problems of institutional provision of modern administrative reforms in Ukraine.

\section{1. Вступ}

Актуальність теми дослідження теоретико-методологічні засади імплементації зарубіжного досвіду адміністративного реформування в умовах децентралізації влади в Україні, загалом зарубіжного досвіду адміністративного реформування, визначення організаційних та інституціональних засад теоретичного аналізу такого досвіду пов'язана 3 тим, що за 27 років незалежності України, як свідчать реалії сьогодення, не вдалося побудувати достатньо функціональну та усталену систему публічної влади, яка була б покликана здійснювати публічно-управлінські функції та надання якісних публічних послуг громадянам України. Такий стан речей обумовлений перш за все, недосконалістю багатьох елементів механізму державного управління, який дістався у спадок від адміністративного режиму радянських часів. Подолати багато недоліків у сфері сучасного публічного адміністрування можливо шляхом здійснення адміністративної реформи, метою якої $є$ поетапне створення на наукових засадах ефективної і демократичної системи державного управління, що має бути достатньо прозорою для громадськості, максимально наближеною до потреб людини, а витрати на іï утримання повинні відповідати фінансово-економічному становищу держави.

Адміністративна реформа виступає одним з напрямів реалізації запропонованої Президентом України Стратегії сталого розвитку [1], що поєднує сучасні концепти «європеізації» публічного управління, формування нової парадигми публічного управління на основі прин- 
ципів New public management, раціонального реагування на зовнішні та внутрішні виклики. Разом з тим, реалізація реформи може бути забезпечена у процесі вирішення проблеми поєднання у часі та у просторі таких інтегративних завдань: формування ефективної системи виконавчої влади на всіх рівнях управління, формування сучасної моделі місцевого самоврядування; формування умов взаємодії виконавчої влади та місцевого самоврядування на основі принципу субсидіарності. У такому форматі важливо врахувати зарубіжний досвід багаторівневого управління, формалізацію феномену делегування повноважень, проведення адміністративно-територіальної реформи тощо

Основу методології статті становлять системний підхід, методи аналізу і синтезу, узагальнення, компаративно-історичний метод відповідно до предмета дослідження. Системний підхід дав змогу дослідити базові елементи державного управління у взаємодії з іншими елементами політичної системи через їх внутрішню інтеграцію. Застосування системного підходу не лише дало змогу проаналізувати організаційно-правові засади діяльності в державному управлінні, їх функціональні ознаки й характеристики, а й визначити загальні тенденції реформування управління. Використання компаративно-історичного методу та системного підходу базувалося на інформації, систематизованої за критеріями аналізу відповідно до характеру дослідження.

У статті також використані класичні наукові принципи об'єктивності та історизму, інші дослідницькі методи: інструментальний, інституційний, соціологічний, аксіологічний, діяльнісний, статистичної обробки емпіричного матеріалу, особистого спостереження та низка інших. Важливим методом дослідження є аналіз фактологічної та емпіричної інформації органів державного управління, результатів соціологічних досліджень для визначення актуальних напрямів підвищення ефективності державного управління в процесі реформування 3 метою врахування тенденцій до змін суспільних відносин.

Так само доцільним було застосування ситуаційного методу, який грунтується на аналізі конкретних ситуацій, виявленні обставин, що впливають на співвідношення національних інтересів у сфері зовнішніх відносин та умов їх реалізації, зокрема виокремлення європейського вибору як основи державотворення в Україні. Кожен із методів у конкретному випадку внаслідок інтегративного підходу до вивчення 
проблеми використовувався не окремо, а в поєднанні з іншими. Варто виокремити два ключових напрями впровадження зарубіжного досвіду адміністративного реформування. По-перше, організаційний, що передбачає визначення основ (принципів, методів та форм) функціонування системи органів влади. По-друге, інституціональний, що визначає сутність діяльності інститутів державного управління та інститутів громадянського суспільства.

У контексті дослідження також слід відзначити роботу Р. Войтович, присвячену дослідженню теоретичних засад глобалізації та іiі впливу на систему державного управління [2]. Зокрема, автор наголошує на необхідності визначення пріоритетів суспільного розвитку як результату впливу глобалізації на систему державного управління. Так само, Р. Войтович вказує на гіперболізацію процесу глобалізму, що провокує ситуацію невизначеності для всієї системи державного управління, й одночасно - на необхідність формування захисних механізмів державного управління [3, с. 322]. Погоджуючись із наведеними підходами провідних науковців, відзначимо, що на даному етапі процеси якісних змін (трансформацій) у національних системах управління є вторинними, і залежать від комплексу факторів внутрішнього та зовнішнього впливу, й окрім глобалізації, факторами ризику для національних держав виступають проблеми самоідентифікації держав, гомогенності національної культури, питання забезпечення національної безпеки.

Разом з тим, рівень наукового опрацювання сучасних процесів адміністративного реформування в контексті використання зарубіжного досвіду потребує більш грунтовного дослідження. Не повною мірою розкриті питання щодо визначення пріоритету впровадження такого досвіду, не визначені адаптаційні інструменти впровадження досвіду реформування, потребують подальшого вдосконалення й методологічні та організаційно-правові засади розробки нормативно-правових документів щодо імплементації зарубіжного доробку у сфері нормотворення для реалізації напрямів адміністративної реформи (розробка, закріплення у нормативних актах, визначення шляхів реалізації відповідних концепцій, стратегій, планів тощо).

Загальною метою дослідження у статті виступає напрацювання організаційних та інституціональних засад впровадження зарубіжного досвіду адміністративного реформування в Україні. Зазначена мета досягається шляхом виконання дослідницьких завдань: по-перше, 
проаналізувати особливості зарубіжного досвіду адміністративного реформування й визначити на цій основі зміст та особливості адміністративного реформування системи державного управління в Україні; розкрити значення організаційного забезпечення здійснення адміністративної реформи для вдосконалення системи публічної влади, роль нормотворчого та законотворчого процесу щодо сприяння реалізації заходів адміністративної реформи; визначити актуальні проблеми інституціонального забезпечення сучасного адміністративного реформування в Україні. Разом з тим, потребують власного вирішення комплекс дослідницьких завдань сучасної юридичної науки у контексті впровадження зарубіжного досвіду (компаративно-адаптаційний підхід). Зокрема, важливо:

- визначити тенденції та особливості впливу сучасних європейських процесів на систему державного управління, у тому числі впливу концептів Європейського адміністративного простору на розвиток національної правової системи;

- уточнити зміст, сутність та правову природу парадигми публічного управління, напрями його сучасного розвитку і на цій основі теоретично обгрунтувати концепцію реформування системи національного права;

- систематизувати сучасні підходи до розподілу управлінських повноважень між різними рівнями публічного управління, дати характеристику основних функцій органів влади на національному та регіональному рівнях у системі завдань формування державної політики і на цій основі обгрунтувати необхідність дослідження інституту делегованого управління та делегованих повноважень;

- охарактеризувати політико-правові механізми гарантування, та захисту прав людини у контексті гуманізації державного управління.

Таким чином, мова йде про виокремлення системного дослідження реформування публічного управління, в основу якого покладено компаративно-адаптаційну модель реформування та принцип гуманізації державного управління. Водночас, доцільно обгрунтувати узагальнений комплекс засобів удосконалення публічного управління на наддержавному, центральному, регіональному й галузевому рівнях через поєднання технологій соціально-економічного розвитку й організаційно-управлінських механізмів, а також дослідити їх специфічні зв'язки. При цьому сутність інструментів адміністративно-правового регулю- 
вання таких процесів визначено через обгрунтування їх імперативного характеру та можливості застосування інноваційних механізмів адміністративного регулювання.

\section{2. Особливості впровадження зарубіжного досвіду адміністративного реформування: організаційні \\ та інституціональні засади}

2014 року почався новий етап адміністративної реформи, у межах якого проведені фундаментальні зміни в системі органів державної влади. Ініційований Президентом України новий курс на модернізацію всієї системи потребує насьогодні у першу чергу принципово нового підходу до адміністративного реформування, розробки концепції формування відкритої системи публічного управління на основі сучасних європейських принципів адміністрування. Важливим завданням формування організаційно-правових засад державного управління в Україні є приведення системи влади у відповідність до світових (європейських) стандартів суспільного управління, 3 урахуванням національних інтересів і процесів структурування наднаціональних систем.

Слід зазначити, що більшість дослідників виходять переважно 3 вузького підходу до розуміння державного управління як об'єкта реформування. Адже реформа державного управління визначається як здійснення цілеспрямованих перетворень, перебудови, удосконалення правового регулювання, результатом яких $є$ поступове формування нової системи державного управління або поява у діючій системі нових якостей, рис або суттєвих ознак. Проте, побудова науково обгрунтованої концепції розвитку державного управління в Україні відповідно до європейських традицій демократичного врядування потребує систематизації сучасних вітчизняних наукових розробок науки управління.

При цьому серед напрямів дослідження впровадження зарубіжного досвіду адміністративного регулювання останнім часом детерміновано достатньо сталий комплекс підходів наукового аналізу. По-перше, визначальне місце займає економіко-правовий підхід, реалізація принципу економічної доцільності, за якого правове регулювання виступає вторинним елементом, який забезпечує раціоналізацію економічних відносин, закріплення суто юридичного принципу недискримінації в контексті впливу економічних факторів (від створення зони вільної торгівлі до економіко-валютного союзу), посту- 
пово доповнюючись соціо-економічним контентом адміністративного регулювання.

По-друге, конституювання в межах сучасних наддержавних інтеграційних процесів норм комунітарного права призвело до формування інституціонально-правового підходу, що закріпив актуальність саме адаптаційної складової впровадження зарубіжного досвіду, оскільки недоцільно фокусувати увагу лише на особливостях правового механізму окремої європейської країни, адже на даний час норми права ЄC та Ради Європи визначають сутність як конституційного процесу в країнах-членах, так і особливості правового регулювання. По-третє, диверсифікація сфер співробітництва, поглиблення взаємозалежності країн-членів ЄС та країн, що закріпили політичний курс на набуття членства, актуалізують системний підхід до дослідження європейського інтеграційного процесу. По-четверте, розвиток наддержавного інтеграційного процесу в інституціональній, політичній і правовій сферах у будь-якому випадку призводять до якісного переосмислення сутності правового регулювання, реформування форм i методів управління у сфері міждержавних відносин. По-п'яте, зміни у функціях національних структур управління, перенесення центру прийняття рішень до інституцій наднаціонального рівня призвело до посилення неофункціонального підходу в методології правового регулювання, напрацюванні особливих правових конструкцій, що дозволяють оперативно вносити зміни у національні норми і стандарти публічного управління. I, по-шосте, формування спільних політик, уніфікація економічних механізмів, гармонізація правових систем потребували запровадження напряму дослідження інтеграційного процесу, що виходить з принципу федералізму, його юридичного змісту. Крім того, малодослідженою виявилась політико-правова сфера наддержавного інтеграційного процесу, система принципів формування i подальшого розвитку регіональних інтеграційних об'єднань та їх правових систем. На часі - напрацювання методології дослідження конституювання інтеграційного процесу як комплексу зовнішніх факторів впливу на суспільні відносини, результатом якого виступає діяльність інституцій управління наднаціонального рівня згідно з принципами, що визначені у договорах ЄС.

Таким чином, в Україні, що перебуває в процесі суспільної трансформації, існує потреба реформування не тільки адміністративної 
системи, а й усієї системи публічного управління в широкому розумінні. Сучасний стан реформування публічної адміністрації з позитивної сторони характеризується тим, що в Україні сформовано більшість інститутів публічної адміністрації, в тому числі, органи виконавчої влади та органи місцевого самоврядування, запроваджено державну службу та службу в органах місцевого самоврядування, створено нову правову базу, що регламентує державне управління та місцеве самоврядування. Водночас, не вирішеними виявились питання адміністративно-правового регулювання відносин органів влади різного рівня, дублювання і водночас, суперечність правових норм, що регулюють діяльність суб'єктів управління.

Зарубіжний досвід правового регулювання суспільних відносин свідчить, що у процесі адміністративного реформування виникає потреба вирішити такі завдання: 1) необхідність і надалі формувати високоефективну організацію виконавчої влади як на центральному, так і на регіональному (субрегіональному) рівнях управління; 2) необхідність формувати сучасну дієву систему місцевого самоврядування в контексті новел національного законодавства та зарубіжного досвіду муніципальної реформи; 3) необхідність запровадження нормативних гарантій раціонального функціонування органів влади щодо забезпечення та реалізації прав і свобод громадян, надання публічних послуг; 4) запровадження раціонального адміністративно-територіального устрою; удосконалення нормативно-правового забезпечення здійснення адміністративного реформування. При цьому аналіз напрямів трансформації державного управління на рівні національної держави у сучасному демократичному контексті розвитку, змін ролі держави в системі взаємовідносин «держава суспільство - людина» дозволяє визначити сучасне публічне управління як вплив держави на стан і розвиток суспільних відносин, поведінку та діяльність особи з метою досягнення цілей і реалізацію функцій держави через діяльність органів влади з урахуванням цілей і завдань всіх суб'єктів публічного управління. Важливим завданням реформування організаційно-правових засад державного управління $\epsilon$ приведення системи влади в Україні у відповідність до світових (європейських) стандартів суспільного управління, 3 урахуванням національних інтересів і процесів структурування наднаціональних систем управління. 
У контексті загальноєвропейських тенденцій адміністративного реформування проблема ефективності державного управління як результату раціонального взаємовпливу політичних та адміністративних аспектів зберігає свою актуальність через поєднання проблемних і малодосліджених сфер адміністративного реформування. По-перше, трансформація системи органів державної влади в контексті принципів адміністративного реформування інститутів $Є С$ та країн-членів $Є С$ (для України - відповідно до Угоди про асоціацію з СС [4]). По-друге, формування нової регіональної політики України, децентралізації управлінських відносин та розвитку механізмів делегованого управління на основі інституціональних змін в системі місцевого самоврядування. По-четверте, європейський вектор розвитку України через запровадження європейських принципів публічного адміністрування.

Аналіз зарубіжного досвіду адміністративного реформування дозволяє дійти висновку, що на етапі впровадження реформ система та підсистеми органів виконавчої влади мають відповідні організаційні структури, які відображають взаємозв'язки між окремими ланками системи і підсистем, субординацію по вертикалі та горизонталі, стосунки 3 вищими органами, підпорядкованими і підконтрольними об'єктами. Оптимальність організаційних структур цієї системи є одним із чинників підвищення ефективності виконавчої влади. Між цими рівнями передбачено субординаційні відносини, й відповідно, системі місцевих органів державної виконавчої влади властиві такі ознаки як: сукупність взаємопов'язаних, тісно взаємодіючих елементів, відносно самостійних за функціональним принципом; внутрішня організованість системи, що перетворює іiі в єдине цілісне явище зі спільною метою.

\section{3. Правовий зміст формування про-европейської моделі правового регулювання в системі публічного управління}

Практика демократизації та різні форми політичної участі населення в суспільному житті європейських країн свідчить, що в умовах зростання багатогранності напрямів діяльності суспільства, його диференціації та індивідуалізації в усіх сферах суспільного життя, будьякий державний апарат настільки віддалений від інтересів індивіда, що не спроможний враховувати місцеві особливості та інші специфічні умови життя громад. Тому цілком логічною є теза, що для більш ефек- 
тивного управління регіонами в країні має зростати роль регіонального і місцевого самоврядування, громадських організацій, які є більш наближеними до інтересів громад і регіонів. У контексті зарубіжного досвіду адміністративного реформування варто зазначити, що новий вимір реформування закладено у сутність сучасного трансформаційного процесу в Україні, зокрема, це стосується децентралізації влади як процесу передання значних повноважень та бюджетних ресурсів від органів виконавчої влади до органів місцевого самоврядування. Саме на основі зарубіжного досвіду формування напрямів місцевого та регіонального розвитку в Україні фактично змінено «ідеологічну» основу публічного адміністрування, адже реформа публічної влади має на сьогодні не латентний характер, а характеризується системним характером, будується на основі принципів сучасного управління (в межах інтегрованих систем публічного управління), і сприймається населенням як сучасний політико-адміністративний тренд.

Саме тому набуває важливого значення розробка сучасної концепції реформування державного управління, що базується на детермінації закономірностей розвитку Української держави в умовах реалізації положень Угоди про асоціацію з СС. Це, по-перше, традиції адміністрування в умовах розвитку національних систем публічного управління країн Свропи. По-друге, закономірності розвитку національних правових механізмів публічного адміністрування. По-третє, особливості виникнення і становлення національної системи публічного управління в Україні. Серед головних проблем, що уповільнюють проведення адміністративної реформи, виступає недостатнє нормативно-правове забезпечення, що обумовлює дискретність реалізації адміністративної реформи, певну дихотомію завдань реформи, засобів реалізації та кінцевого результату. Подолати такі проблеми, мінімізувати негативні прояви у процесі реформ можливо саме на основі раціонального запровадження європейського (зарубіжного) досвіду реформ.

Науковий аналіз політико-правових передумов, історичних етапів та самого феномену європейської інтеграції [5] дозволив охарактеризувати процес впровадження європейського (зарубіжного) досвіду адміністративно-правового регулювання як процес, за допомогою якого окремі країни надають частину своїх суверенних прав на користь утворюваної і єдиної для них усіх інституціональної структури з тим, 
щоб забезпечити врахування і реалізацію спільних інтересів. Це, по-перше, фундаментальні умови: бути європейською державою, мати спроможність і прагнення виконувати основні задачі цієї організації; по-друге, організація вільних виборів: у країні повинні бути демократичні, вільні, із таємним голосуванням і справедливі національні загальні вибори; по-третє, захист прав людини й основних свобод: держава, що визначає себе як європейська, повинна бути готова підписати і ратифікувати Конвенцію прав людини та основоположних свобод Ради Європи, а також інші документи, підписані і ратифіковані всіма членами конвенції; по-четверте, демократичність політичної і конституційної системи: досліджуються положення конституції про заснування демократичних інститутів, закон про вибори, положення щодо демократії на місцевому рівні, участь жінок в інститутах влади, свобода асоціацій, свобода профспілок, свобода преси і засобів масової інформації; по-п'яте, верховенство закону: досліджуються система захисту прав людини, зокрема, права національних меншостей, юридична система.

Саме тому доцільно з позицій аналізу конституційно-правових засад реформування державного управління в умовах євроінтеграційних процесів визначити етапи становлення, проблеми, структурні характеристики та тенденції організаційного розвитку національних систем управління в умовах сучасних євроінтеграційних процесів, встановити сталі динамічні тенденції розвитку національної держави та трансформації державного управління у такому процесі. При цьому слід врахувати напрацювання науки державного управління, юридичної, економічної та політичної наук задля системного оновлення демократичної концепції державного управління, адаптацію такої концепції до умов перехідного суспільства. За таких умов сучасна концепція модернізації може бути презентована суспільству як програма 3 довгостроковими пріоритетами, та може бути використана в якості теоретичної моделі при розробці нового та уточненні положень чинного національного законодавства у сфері державного управління та державної служби. На таких засадах розкриваються у новому аспекті особливості становлення та організаційно-правові засади управлінської діяльності в складних адміністративних системах, отримує самостійну наукову концепцію методологія адміністративно-правових засобів забезпечення прав і свобод громадян в умовах наддержавних інтеграційних 
процесів, оптимізується система класифікаційних ознак гармонізації міжнародного та національного законодавства щодо здійснення управлінської діяльності; обгрунтовується доцільність застосування методології системного аналізу до трансформаційних процесів в державно-управлінській діяльності за окремим науковим напрямом. Отже, нагальність системного дослідження організаційно-правових засад трансформації державного управління в контексті євроінтеграційних процесів визначається важливістю вирішення проблеми раціоналізації державно-управлінських відносин у сучасних умовах розвитку міждержавних зв'язків, міжнародної економічної інтеграції, глобалізації процесів суспільного управління.

У таких умовах набуває важливого значення розробка сучасної парадигми реформування державного управління, що базується на детермінації закономірностей розвитку національної держави в умовах євроінтеграційних процесів. Це, по-перше, закономірності розвитку національних систем публічного управління країн Європи. По-друге, закономірності розвитку національних систем публічного управління країн пострадянського простору. По-третє, закономірності розвитку національної системи публічного управління в Україні.

Системний аналіз напрямів трансформації державного управління на рівні національної держави у сучасному демократичному контексті розвитку національної держави, змін ролі національної держави у міжнародних відносинах дозволяє визначити сучасне державне управління як вплив держави на стан і розвиток суспільних відносин, поведінку та діяльність особи з метою досягнення цілей і реалізацію функцій держави через діяльність органів влади з урахуванням впливу наднаціональних чинників. Важливим завданням реформування організаційно-правових засад державного управління $є$ приведення системи влади в Україні у відповідність до світових (європейських) стандартів суспільного управління, з урахуванням національних інтересів і процесів структурування наднаціональних систем управління.

Саме тому характерною ознакою реформування державного управління на сучасному етапі державотворення в межах складних адміністративних систем є вплив зовнішньополітичних факторів, наднаціональне спрямування трансформації державного управління, розвиток принципово нового типу управління - делегованого управління. Водночас, напрацювання концептуальної основи раціоналізації суспільних 
відносин, що складаються у сферах державного управління, впливають на процеси суспільного та державного життя, а також безпосередньо пов'язані зі здійсненням органами виконавчої влади та їх посадовими особами адміністративно-правової діяльності із застосуванням інноваційних форм і методів, потребує самостійного дослідження феномену складних адміністративних систем в умовах інтеграційних процесів.

У цьому зв'язку слід підкреслити, що певна універсальність регулятивних механізмів у системі державного управління призводить до узагальненості державно-управлінських рішень у суспільно-політичній сфері на центральному рівні та зниженні ефективності управлінських рішень на регіональному та місцевому рівнях. У той самий час, переважна більшість політичних партій України функціонують лише на національному рівні, за практичної відсутності (або формальній наявності) регіональних структур, що негативно впливає на можливість загальнодержавного діалогу, адаптованого до регіональних проблем. За таких умов, у період реформування політичної системи України виникли дві сторони співвідношення «політика - влада» як прояву дихотомії політичної влади. По-перше, надмірна політизація владних відносин, зведення політики над владою, домінування політичних факторів у всіх сферах управління. По-друге, наукова проблема заперечення політичного у владі, зведення влади до економічно-господарських функцій. Такий стан речей пояснюється несистемним усвідомленням ролі державного управління у розвитку суспільних відносин. Таким чином, управління як особливий вид діяльності, що виконує роль організації та координації суспільних відносин, втрачає можливість до раціоналізації, набуває характеру «консервативної сталості».

Перед системою влади в Україні у процесі трансформації постали принципово нові завдання. Перш за все, важливо у процесі реформування на основі практики міжнародного менеджменту розробити програмні засади удосконалення механізмів інтеграційної політики України та визначити шляхи їх впровадження в практику формування та раціоналізації управлінських механізмів країни. Так само, у процесі реформування необхідно на рівні державних цільових програм удосконалити правові засади державної політики в умовах участі України в наддержавних інтеграційних процесах, й задля цього необхідно уточнити методологічні орієнтири і критерії раціональної державно-управлінської діяльності. 
Варто наголосити у контексті імплементації зарубіжного досвіду адміністративного реформування, що у межах функціонування $\mathrm{CC}$ Європейський адміністративний простір (ЄАП) виступає у вигляді відкритої інтегрованої системи публічного управління на наднаціональному рівні, яка: грунтується на принципах європейського права, функціонально, структурно і предметно базується на ключових принципах договорів про Європейський Союз, закріплена нормами національного законодавства країн-членів, включає правові засади співробітництва з європейськими країнами - не членами СС в межах дво- та багатосторонніх угод, реалізує програмні положення відносин з групами держав в межах Європейського континенту, формує принципи регіонального, транскордонного та міждержавного співробітництва, регулює суспільні відносини на різних рівнях управління, i, водночас, між органами управління і громадянами, забезпечує дотримання норм права у різних сферах соціального управління, перш за все, щодо дотримання прав і свобод громадян, i інтегрально пов'язує економічні, політичні, соціальні та гуманітарні аспекти управління в складних адміністративних системах. Як і будь-яка адміністративна система, САП формалізований через низку публічно-правових норм, що напрацьовані у процесі формування на теренах Європи сучасних національних держав та наднаціональних утворень.

Сучасні дослідження інститутів публічного управління у наукових працях практично завжди пов'язувалися 3 одночасним розглядом питань, що стосувалися адміністративно-правових форм публічно-управлінської діяльності [6]. Це пояснюється тим, що публічне управління має універсальний характер, знаходить свій прояв у суспільному житті через властиві лише у публічно-правовому контексті процедури. Саме тому вважаємо, що публічне управління як система суспільних відносин у контексті формування європейського адміністративного простору передбачає:

- застосування нової методології аналізу організації державно-управлінської діяльності щодо реалізації інтеграційної політики України та визначення критеріїв і показників ефективності дій владних структур на центральному та регіональному рівні управління;

- встановлення правових засад інституціоналізації механізмів державного управління $з$ огляду на їх важливість 3 точки зору забезпечення прав і свобод громадян національних держав; 


\section{Theoretical and methodological basis of implementation of the foreign...}

- виокремлення сутності, правової природи та принципів регулювання процесів управління, іманентних їм критеріїв класифікації,визначається принципами європейського адміністрування на рівні наднаціональних структур.

\section{4. Висновки}

Актуальність наукового аналізу зарубіжного досвіду адміністративного реформування зумовлена комплексом факторів. До найголовніших 3 них належить: по-перше, той факт, що на етапі суспільно-політичних трансформацій в Україні відсутня достатньо усталена система суспільно-значимих пріоритетів адміністративного реформування, що сприймаються суспільством як визначальний напрям розвитку держави. При цьому концептуальні засади саме адміністративної реформи не сформовані у адміністративно-політичному й суспільному сприйнятті як цілісна програма національного розвитку, а виступають частиною загальної стратегї національних реформ. Саме тому в контексті загальноєвропейського досвіду адміністративного реформування стала очевидною загальна тенденція до посилення ролі держави як суб'єкта політичної влади та одночасного звуження їі ролі як безпосереднього суб'єкта в системі локального і регіонального управління. Такий стан певною мірою пояснюється політичними факторами, i разом $з$ тим, актуалізує проблему нормативного закріплення положень адміністративного реформування.

Демократизація публічної адміністрації виступає однією 3 передумов інтеграції України до європейських і світових політичних та економічних структур, зокрема і до ЄС. Йдеться про реформування, насамперед, центрального апарату, що займається державним управлінням. 3 позицій напрацювання методології дослідження зазначимо, що зазвичай, у вітчизняному державному управлінні використовується термінологія, що перейшла ще з радянської адміністративно-правової доктрини; добре відомий усім термін «державне управління» є перекладом поняття «публічна адміністрація», хоча при детальнішому зіставленні цих категорій видно, що вони не є тотожними (друге $є$ значно ширшим). I, взагалі, що стосується пострадянської адміністративно-правової доктрини, то, як зазначає більшість науковців, вона відображає й обслуговує так звану «державоцентристську» ідеологію, при якій державницькі інтереси, тобто «благо держави», превалюють 
над інтересами людини i, зрештою, всього суспільства. На противагу цьому, в основу нової адміністративно-правової доктрини має бути покладена протилежна - «людиноцентристська» - ідеологія, згідно 3 якою держава має «служити» інтересам громадян шляхом всебічного забезпечення пріоритету їх прав, свобод та інтересів у сфері діяльності органів публічної адміністрації: органів виконавчої влади та органів місцевого самоврядування.

Уточнено зміст, сутність та правову природу сучасної парадигми публічного управління. Власне, процес адміністративного регулювання в ЄС побудований на загальновизнаних правилах і процедурах суспільного управління, характеризується відсутністю будь-якої дискримінації, довів власну ефективність у контексті сучасних глобалізаційних процесів. Аналіз законодавства європейських країн, міжнародно-правових документів, зарубіжного, зокрема європейського, управлінського досвіду, дає підстави стверджувати, що власна, національна система публічного управління в Україні має бути визначена через дотримання правил і процедур демократичного врядування, формалізованих у процесі європейської інтеграції та розкритих у контексті поняття «європейська ідентичність» як у правових актах $С \mathrm{C}$, так і в двосторонньому форматі відносин «Україна - ЄС». Саме на засадах історико-теоретичного аналізу сучасних умов трансформації суспільних відносин в Україні варто базувати процес імплементації зарубіжного досвіду

\section{Список літератури:}

1. Про Стратегію сталого розвитку «Україна-2020»: Указ Президента України від 12 січня 2015 року № 5/2015: Режим доступу: http://www.president. gov.ua/documents/18688.html).

2. Войтович Р. Регіоналізація як обернена форма глобалізації та ії вплив на систему державного управління / Р. Войтович // Вісн. НАДУ. - 2007. № 2. - С. 15-25.

3. Войтович Р. В. Вплив глобалізації на систему державного управління: дис. ... д-ра наук з держ. упр.: 25.00.02 / Войтович Р. В. ; Нац. акад. держ. упр. при Президентові України. - К., 2009. - 403 с.

4. Виконання Угоди про асоціацію між Україною та ЄС [Електронний pecypc] / Кабінет Міністрів України // Режим доступу: http://www.kmu.gov. ua/control/uk/publish/article\%3fart_id=247749544\&cat_id=247749488 - Назва 3 екрану.

5. Wallace H. EU Enlargement: A Neglected Subject / H. Wallace // Cowles M., Smith M. The State of the European Union: Risks, Reform, Resistance and Revival. - Oxford : Oxford University Press, 2000. - Vol. 5. - P. 149-164. 
6. Olechowskij A. Four Premises for the Polish Strategy in the European Union. / A. Olechowskij // The Polish Foreign Affairs Digest. - 2003. - Vol. 3. N. 4(9). - P. 2335.

\section{References:}

1. Pro Strategiyu stalogo rozvytku "Ukrayina-2020»: Ukaz Prezydenta Ukrayiny vid 12 sichnya 2015 roku № 5/2015: Rezhym dostupu: http://www. president.gov.ua/documents/18688.html).

2. Vojtovych R. Regionalizaciya yak obernena forma globalizaciyi ta yiyi vplyv na systemu derzhavnogo upravlinnya / R. Vojtovych // Visn. NADU. 2007. - № 2. - P. 15-25.

3. Vojtovych R. V. Vplyv globalizaciyi na systemu derzhavnogo upravlinnya: dys. ... d-ra nauk z derzh. upr.: 25.00.02 / Vojtovych R. V. ; Nacz. akad. derzh. upr. pry Prezydentovi Ukrayiny`. - K., 2009. - 403 p.

4. Vykonannya Ugody` pro asociaciyu mizh Ukrayinoyu ta ES [Elektronnyj resurs] / Kabinet Ministriv Ukrayiny // Rezhym dostupu: http://www.kmu.gov.ua/ control/uk/publish/article\%3fart_id=247749544\&cat_id=247749488 - Nazva Z ekranu.

5. Wallace H. EU Enlargement: A Neglected Subject / H. Wallace // Cowles M., Smith M. The State of the European Union: Risks, Reform, Resistance and Revival. - Oxford : Oxford University Press, 2000. - Vol. 5. - P. 149-164.

6. Olechowskij A. Four Premises for the Polish Strategy in the European Union. / A. Olechowskij // The Polish Foreign Affairs Digest. - 2003. - Vol. 3. No. 4(9). - P. 23-35. 